\title{
Exploring Reciprocal Teaching Method on EFL Learners' Reading Comprehension
}

\author{
Ahmad Ridho Rojabi \\ Universitas Islam Negeri Kiai Haji Achmad Siddiq Jember, Indonesia \\ Correspondence* \\ ahmadridhorojabi@gmail.com
}

\section{Submission History:}

Submitted: July 30, 2021

Revised: September 01, 2021

Accepted: September 06, 2021

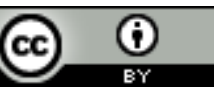

This article is licensed under a Creative Commons Attribution 4.0 International License.

\begin{abstract}
This research was carried out as the learning activities in the reading classroom were not yet effective. As a result, the student's ability to comprehend reading texts was poor. This study aims to improve the EFL students' reading comprehension by implementing the Reciprocal Teaching Method (RTM), especially in comprehending IELTS reading texts. Classroom action research was conducted by following four stages; planning, implementing, observing, and reflecting the actions. The Reciprocal Teaching Method (RTM) consists of four stages; predicting, questioning, clarifying, and summarizing to engage the learners in groupwork activities, boost motivation, as well as enhance their comprehension. 28 learners from the English department who enrolled in the Reading course were selected as participants. Data were gathered through observations, tests, interviews, as well as document reviews. The results revealed that the Reciprocal Teaching Method (RTM) boosts students' ability to comprehend the IELTS reading texts and engages them during the teaching and learning process.
\end{abstract}

Keywords: classroom action research, reciprocal teaching method, reading comprehension

\section{INTRODUCTION}

Reading is one of the important language skills as a receptive skill; nevertheless, without proper skills and comprehension, reading proficiency is difficult to achieve (Spivey, N., R. \& Cuthbert, 2006). Reading is activities to gain meaning from the texts (Snow, 2002; Westerveld et al., 2020). Reading comprehension is defined as the activities in receiving the message from the texts (Peregoy \& Boyle, 2017; Zhang, 2018). Based on the explanation above, reading comprehension is the process of interaction between the writer 
and the reader in which the writer encodes a message while the reader decodes the meaning from the text.

However, some students get difficulties to gain the text's meaning comprehensively. Their difficulty in comprehending the text is due to low reading interest and insufficient reading strategies (Spear, 2015). By doing so, the problems faced by most EFL learners need to be highlighted and solved. Based on the observation and interview in the preliminary study, the students' participation and engagement in reading class were low, they seemed passive and unmotivated in the class. Besides, they could not read the text properly and got a difficulty using the dictionary.

Due to their concerns about comprehension challenges, the Reciprocal Teaching Method (RTM) can be a solution to overcome the learners' challenges in reading comprehension (Ofodu \& Lawal, 2011). RTM was created to help learners enhance their reading comprehension at all levels and across all topics. Cooperative learning is a learning strategy consisting of four persons in small groups, it provides equal opportunities for all learners to participate and achieve the learning goals (Renandya \& Jacobs, 2017; Rojabi, 2021). The success of learning depends on the activities of members in a group. In cooperative learning, the learners from heterogeneous abilities need to discuss the assigned materials cooperatively. RTM is a cooperative learning practice where members of a group engage and help each other to increase their reading comprehension (Tarchi \& Pinto, 2016). Cognitive methods are given to students to assist them in deriving meaning from texts as well as monitoring their comprehension (Blazer, 2007).

Predicting, querying, clarifying, and summarizing are four comprehension processes used by RTM (Brown \& Palinscar, 1984). These strategies allow students to keep track of their reading comprehension progress (Hosenfeld, et al., 1993). The students in a reading classroom can be divided into groups of four or five. A group will be divided into five roles: a leader, a predictor, a clarifier, a questioner, and a summarizer. Furthermore, RTM does not only assist students in English but also assists them in Mathematics as well as Physics from the level of primary to University (Meyer, 2014; Quirk, 2010). In brief, RTM was implemented in boosting learners' comprehension.

A model of Reciprocal Teaching as a teaching method is applied by the researcher in teaching reading comprehension. In general, the guideline of applying the RTM was used in teaching reading. More specifically, to teach reading through the RTM, the procedures follow these stages: (a) A group of four students is chosen, and each is assigned a certain duty, which includes a predictor, a questioner, a summarizer, and a clarifier. (b) Next, the pupils were asked to read a paragraph of text to the class, they were recommended to take notes while reading, such as highlighting, coding, and so on. (c) Before reading, the student who was chosen as a predictor assists his peers in connecting earlier sections of the text by providing a prediction based on cues provided by the title or visuals. The leader then instructs them to meet with their team to discuss their predictions. They are instructed to re-read the materials to validate their predictions. The student who was chosen as a 
questioner assists his group in asking and answering questions about the text to obtain more knowledge. The summarizer's job is to assist his group in identifying the ideas and details and making a summary as well. The clarifier assists the group in identifying and resolving confusing areas (words and sentences). (d) When the assigned text has already been read, the students in each group switch roles. They go through the process again, this time following their new role. And (e) The trainer directs the learners to exploit the four strategies independently (Oczkus, 2010).

The previous research related to RTM was conducted by Komariah et al., (2015). They examined the benefits of the Reciprocal teaching method, the learners' achievement as well as the 24 learners' perceptions from twelfth graders at a high school in Banda Aceh. The data were collected through observations, tests, documents as well as interviews. The results revealed that the learners' participation was increased during reading classroom by implementing RTM and the learners' comprehension improved.

Another research was conducted by Okkinga et al., (2016). They examined the effectiveness of RTM for the learners' comprehension. Over one year, 10 experimental teachers and 10 control teachers were selected. The experimental teachers implemented the RTM, while 10 control teachers implemented the conventional method. The observations focused on the instruction of reading strategies, modeling, and collaboration for 369 teenage students. The results revealed that RTM could enhance the slow learners' comprehension as the teacher implemented the instruction of reading strategies properly.

Many previous studies have explored RTM in reading classes to find out the effectiveness of RTM in facilitating students' motivation, boosting their participation, and improving their reading comprehension. However, few studies have explored RTM in improving the learners' reading comprehension in the context of IELTS. Concerning the above background, the purpose of this study is to investigate the use of the Reciprocal teaching method in improving the EFL students' reading comprehension and the research question is "How successful is the exploitation of the Reciprocal Teaching Method for the improvement of EFL students' reading comprehension?.

\section{METHOD}

This Classroom Action Research was conducted to enhance the learners' reading comprehension of the English department at UIN KHAS Jember. The participants were the 28 students of the English department who enrolled in the Reading class, while data were gathered through observations, interviews, tests, as well as document review. An observation checklist was developed based on the indicators of RTM, while the test was validated by an expert for content validity before it was given to the learners. In the observation stage, the learners' participation and engagement in reading class were observed by using an observation checklist, the semi-structured interview was given to 6 students to explore their experiences and perceptions of RTM in reading class, the test was administered after the actions to know the learners' improvement on reading 
comprehension, while document review was required to collect the data related to students' presence, gender, age, and the total number of the participants in the class, syllabus, lesson plans, school profile, and vision and mission of the school. The data were then analyzed and presented descriptively in every cycle. The data were related to each other, after the data from observation was gained, it was then compared with the results gained from the interviews and reading test to check whether RTM could enhance the learners' reading comprehension and their engagement in the classroom or not.

The students who were taught using RTM were observed. The class met twice, with 90 minutes for each meeting. In the first meeting, the students were taught reading using RTM and were given some explanations related to IELTS reading texts as IELTS was not common for some of them, then they were asked to read one IELTS reading text and to comprehend it individually. They were assisted to record important information in the reading texts, ask questions based on the texts, restate the main points, answer the questions related to the contents, and clarify some difficult words. At the second meeting, the learners were divided into groups and were assigned to implement RTM based on their different roles: a predictor, a questioner, a clarifier, and a summarizer. A leader directs his group in exploiting the stages or procedures of RTM, a predictor assists his group by providing a prediction based on cues provided by the title or visuals on the texts. The questioner assists his group in asking and answering questions about the text to gain more information. The clarifier assists his group in identifying difficult or confusing words and sentences. The summarizer assists his group in identifying the ideas and details and making a summary.

The duration of this research is within three months, from January to March 2020. The research procedure consists of planning, acting, observing, as well as reflecting on the actions. In the planning stage, a Learning Plan (RPP) was constructed, the scenarios were developed, the observation sheets were prepared, and the learning evaluation was developed. The implementation of the action was carried out in two cycles, each cycle consisting of two meetings. The observation stage was carried out by observing the students' participation in the classroom. In the reflection stage, analysis and evaluation were carried out to reflect on the implementation of the RTM method that has already been applied in the reading classroom.

\section{RESULTS AND DISCUSSION}

The results of the pre-test revealed that learners' reading comprehension was still poor. The percentage of the learners who achieved the targeted score of reading 60 as the minimum achievement criteria were $35.71 \%$ (10 students), while the percentage of the learners who did not achieve the targeted score was $64.28 \%$ (18 students). The lowest score reached 25 , the highest score reached 80 , and the average score on the pre-test was 51.07 (see Table 1). 
Table 1. The Students' Achievement in Pre-test

\begin{tabular}{lll}
\hline No & Statement & Percentage \\
\hline 1 & The percentage of the learners who achieved the targeted score & $35.71 \%(10$ \\
& & students) \\
2 & The percentage of the learners who did not achieve the targeted & $64.28 \%(18$ \\
& score & students) \\
3 & Mean score & 51.07 \\
\hline
\end{tabular}

In cycle 1 , there were $57.14 \%$ (16 students) who did not achieve the minimum achievement criteria, while $42.85 \%$ (12 students) reached 60 or greater than 60 . The lowest score was 25 , the highest score was 80 , and the mean score of the reading test was 52.14. The study was continued to the second cycle as the research performance indicators, in which $75 \%$ of students who achieved a score of 60 as the minimum achievement criteria had not been achieved (see Table 2).

Table 2. The Students' Achievement in Cycle 1

\begin{tabular}{lll}
\hline No & Statement & Percentage \\
\hline 1 & The percentage of the learners who achieved the targeted score & $42.85 \%(12$ \\
& & students) \\
2 & The percentage of the learners who did not achieve the targeted & $57.14 \%$ (16 \\
& score & students) \\
3 & Mean score & 52.14 \\
\hline
\end{tabular}

Indicators of reading comprehension used in this research are; 1) record important information in the reading texts, 2) make questions based on the texts, 3) restate what has been read, 4) answer the questions related to the contents of the texts, 5) clarify some difficult words, and 6) make conclusions (Brown, 2007). Those indicators are adapted based on the problems found in the reading classroom and the learners' characteristics. Each indicator was assessed by distributing IELTS reading texts to each student. Every student was given 60 minutes to read, comprehend the texts, and answer the 20 questions provided. The teacher could give a score of 5 for every correct answer.

In IELTS reading, there are 3 reading passages with 40 questions. The materials are taken from books, magazines, and newspapers. The learners need to successfully answer various formats of multiple-choice, sentence completion, answer and question connection, diagram completeness, matching lists, as well as short answer questions. Thus, the learners are expected to answer the questions properly based on the indicators mentioned.

In the first cycle, some students were still confused and were crowded in their groups because they were not accustomed to applying this method. Several students got difficulty in finding the main idea from the text so that the teacher needed to re-explain how to find the main idea in a text. In the process of making questions, some students also got difficulty using WH-questions as they seemed struggling to use the WH questions due 
to limited vocabulary, low motivation, and low self-confidence. Some students could answer the questions in their group discussion, however, they just wrote down the unappropriated answers with the context.

Each indicator can be specifically reported as follows; 1) In setting group work and recording important information from the text, $14 \%$ or four students could discuss and write the main ideas related to the text. However, several students seemed unmotivated, they did not focus on the teacher's explanation and could not write the main ideas of the text. Some learners could find the literal information but they were struggling with inferential comprehension. 2) In the stage of making questions, $36 \%$ or 10 students could make WH questions (what, who, where, when, and why) related to the text. However, several students could not create questions with the appropriate WH questions and some questions were out of context. Some learners were struggling to highlight ideas on the text about the person, the place, or the time. 3) In the stage of restating the ideas, $18 \%$ or five students could restate and discuss the main ideas as well as the details in front of the class confidently. 4) In the stage of answering the questions, $36 \%$ or ten students were motivated to raise their hands and answered some questions provided in front of the class confidently. 5) In the stage of clarifying, $21 \%$ or six students could write some difficult words. Some learners could highlight some difficult words and initiatively tried to check the meaning in the dictionary. Some of them tried to consult with their peers and checked the meanings and synonyms on the internet by browsing the websites of https://www.merriam-webster.com/ or https://www.oxfordlearnersdictionaries.com/. 6) In the stage of summarizing, $36 \%$ or ten students could create conclusions in their own words. However, some students were struggling with how to paraphrase the text.

The following are the interview excerpts with students related to the problems in applying RTM to find the main ideas, predict the content, ask questions, clarify, and summarize the text.

"It is not easy to find the main ideas as I have limited vocabularies" (S3)

"Making questions is the hardest. I have no idea what I should do" (S1)

"I have so many difficult words from the text, I need to check the meaning on the dictionary and discuss it with friends (S2)

"Well, it is easy to make a summary but it is still difficult to make it in our own words (S4)

"By looking at the title, we can predict the content, but I am still confused to find the main ideas of the text (S6)

From the findings in the first cycle, it can be reported that some students still got difficulty working together and played their roles in their respective groups. Students with the questioning role were still confused to make some questions based on the texts. It happened as they unsuccessfully found the main ideas of the reading text. Meanwhile, 
students with clarifying roles still had difficulty in finding difficult words due to the limited vocabulary they had, and they needed more time to access the dictionary. Concerning those reasons, revisions for the second cycle were required. The teacher as a facilitator then tried to re-explain the procedures of RTM both in English and Bahasa Indonesia, provided dictionaries and fun activities while discussing the topic, and gave more enjoyable practices as well. Furthermore, the facilitator directed the learners to work cooperatively and to help each other. The fast learners were permitted to help the slow learners when they got difficulty in playing their roles.

Furthermore, in the second cycle, there was $17.85 \%$ (5 students) who still got a score under 60 as minimum achievement criteria, while 82.14\% (23 students) reached 60 or greater than 60 . The student's lowest score of reading was 25 , while the highest score was 90, and the reading test's mean score was 74.46 . The test results of students' reading scores had met the indicators of performance that was $75 \%$ of students had successfully reached 60 as the minimum achievement criteria. Thus, the action was completely stopped in the second cycle (see Table 3).

Table 3. The Students' Achievement in Cycle 2

\begin{tabular}{lll}
\hline No & Statement & Percentage \\
\hline 1 & The percentage of the learners who achieved the targeted score & $\begin{array}{l}82.14 \%(23 \\
\text { students })\end{array}$ \\
& & $\begin{array}{l}\text { The percentage of the learners who did not achieve the targeted } \\
17.85 \%(5\end{array}$ \\
& score & students) \\
3 & Mean score & 74.46 \\
\hline
\end{tabular}

In the second cycle, the learners got good results and their comprehension got improvement in each indicator. By applying RTM, the student's engagement in the second cycle got improvement. 1) In setting group work and recording important information from text, students successfully discussed and wrote the main ideas related to the text. 24 students or $86 \%$ were motivated, they focused on the teacher's explanation and could write the main ideas of the text better. Besides, some students initiatively read more, they searched for specific ideas by skimming and scanning, and answer literal and inferential information from the texts. 2) In the stage of making questions, $82 \%$ or twenty-three students could make WH questions (what, who, where, when, and why) related to the text. They were struggling to make questions by talking with their classmates about the general and specific ideas related to the topic of reading. However, several students could not create questions with the appropriate WH question and some questions were out of context. 3) In the stage of restating the ideas, $82 \%$ or twenty-three students could restate and discuss the main ideas as well as the details in front of the class confidently. 4) In the stage of answering the questions, $86 \%$ or twenty-four students were motivated to raise their hands and answered some questions provided in front of the class confidently. 5) In the stage of clarifying, $93 \%$ or twenty-six students could write some difficult words. They 
highlighted and took notes of the difficult words and checked their meaning in the dictionary. Some of them tried to consult with their peers and checked the meanings and synonyms on the internet by browsing on the websites of https://www.merriamwebster.com/ or https://www.oxfordlearnersdictionaries.com/. 6) In the stage of summarizing, $93 \%$ or twenty-six students could create conclusions even though two students could not create a conclusion with their own words, they just copied from the original version of the text. Not only did they successfully create a conclusion but also did they confidently discuss the information that they read in front of the class.

The activities were enjoyable, as a result, the students could cooperatively discuss the materials with their groups, and they were cooperative doing their roles. Besides, some of them enjoyed reading the text silently, some students successfully clarified the main ideas and details, and others were enthusiastic in making questions related to the texts. The RTM emphasized student-centered and the students became active in group discussion. By implementing RTM cooperatively, the learners successfully wrote down some important information from the texts, asked questions in front of the class, discussed the main idea as well as the details with friends, answered all the questions, looked for the difficult words, and concluded the reading text. The RTM was carried out by peer tutors so that students could share their opinions, the fast learners could assist slow learners in finding the ideas and could discuss the topic together as well, while the teacher played his role as a facilitator.

The following are the interview excerpts with students related to the students' experiences by applying RTM in finding the main ideas, predicting the content, asking questions, clarifying, and summarizing the text.

"Well, I can guess what the text will talk about by looking at the picture or title"(S2)

"By working together, finding the main ideas becomes easier" (S3)

"This method is helpful, I can easily ask questions related to content. Sometimes I ask another friend when I find difficult words" (S1)

"We learn to work together and take our responsibility based on our roles" (S5)

"We need to highlight some words like person, place or time before making questions (S6)

"Clarifying is the easiest part, if I do not know the meaning, I just need to check it on the dictionary or ask friends (S3)

It is important to give a good explanation as well as instruction of the RTM method not only in English but also in Bahasa Indonesia in reducing miscommunication, By doing so, the slow learners could implement the strategies properly. In its application, RTM is quite challenging for students with low English proficiency due to the complicated procedures. Therefore, teachers often explain instructions in applying the RTM method repeatedly. This is consistent with Hacker and Tenent's findings (2002). In their research, 
the teachers got difficulty in directing the learners to work cooperatively, they needed to explain the procedures of RTM clearly.

As reported on the observations as well as the interviews, this study indicated that RTM could motivate the learners' participation in fun and cooperative activities and could facilitate and improve the learners' comprehension. During the classroom reading activities, they became more active, strategic, and cooperative, thus they successfully implemented the RTM and could comprehend the reading text better. This finding is consistent with the previous studies that claim that RTM improves students' reading comprehension (Choo \& Ahmad, 2011; Freihat \& Al-Makhzoomi, 2012; Salehi \& Vafakhah, 2013). Choo \& Ahmad (2011) report their experimental research with 68 learners as participants. After exploiting RTM in reading class over one month, the experimental group resulted in an improvement in their reading comprehension. Freihat \& Al-Makhzoomi (2012) report the effectiveness of RTM for 50 Jordanian university students after the treatment. Comparing the scores between pre-test and post-test, the results revealed a significant improvement in the learners' reading comprehension. Furthermore, Salehi \& Vafakhah (2013) investigate the difference between Reciprocal Teaching Only (RTO) and Explicit Teaching of strategies before Reciprocal Teaching (ET-RT) on the reading comprehension of Iranian female EFL learners. The results revealed that RTO managed the Iranian female learners reading comprehension and ET-RT managed the EFL learners' comprehension better.

\section{CONCLUSION}

The results revealed that the RTM could facilitate the learners' reading comprehension and improve their engagement in reading class. By implementing RTM in reading activities, the learners become more creative and helpful. As seen in the reading classroom, they are actively participated in discussing the texts cooperatively. They are more eager to read after employing the four strategies to comprehend the texts. In brief, the reciprocal teaching method helps the students to predict, ask some questions, clarify as well as summarize the text in the teaching-learning process of reading.

Teachers should give appropriate explanations, provide models explicitly, motivate and increase students' responsibility to play their role in RTM. Besides, the learners need to work cooperatively, and they need to help each other. Furthermore, the teacher is required to listen and pay attention to student interactions, properly direct the four strategies in RTM so that the learning activities in the reading class can be successfully achieved.

Thus, future researchers are suggested to adapt the implementation of RTM as it is one of the successful strategies. The RTM can be explored in a wider class of reading or other skills. They may conduct a similar research approach, qualitative research, or different research approach in boosting the learners' motivation and engagement during the teaching-learning process of reading. 


\section{REFERENCES}

Blazer, C. (2007). Reciprocal teaching. Research Services of Miami-Dade County Public Schools. 6(9), 1-15.

Brown, A. L., \& Palinscar, A. S. (1984). Reciprocal teaching of comprehension- fostering and comprehension-monitoring activities. Cognition and Instruction, 1(2), 117-175.

Brown, H. D. (2007). Teaching by principles. An interactive approach to language pedagogy (Third Edit). New York: Pearson Education, Inc.

Choo, T. O. L, Eng, T. K., \& Ahmad, N. (2011). Effects of reciprocal teaching strategies on reading comprehension. The Reading Matrix, 11(2), 140-149.

Freihat, S., \& Al-Makhzoomi, K. (2012). The effect of the Reciprocal Teaching Procedure (RTP) on enhancing EFL students' reading comprehension behavior in a university setting. International Journal of Humanities and Social Science, 2(5), 279-291.

Hacker, D.J. \& Tenent, A. (2002). Implementing reciprocal teaching in the classroom: Overcoming obstacles and making modifications. Journal of Educational Psychology, 94(4), 699-718. https://doi.org/10.1037//0022- 0663.94.4.699

Hosenfeld, C., Cavour, I., Bonk, D., Baker, L., \& Alcorn, M. (1993). Activities and materials for implementing adapted versions of reciprocal teaching in beginning, intermediate and advanced level of instruction in English, Spanish and French as a second language. ERIC $\begin{array}{lllll}\text { Document } & \text { Reproduction } & \text { Service } & \text { No. }\end{array}$ http://files.eric.ed.gov/fulltext/ED370354.pdf

Komariah, E., Ramadhona, P. A. R., \& Silviyanti, T. M. (2015). Improving reading comprehension through reciprocal teaching method. Studies in English Language and Education, 2(2), 87-102. https://doi.org/10.24815/siele.v2i2.2693

Meyer, K. (2014). Making meaning in Mathematics problem-solving using the reciprocal teaching approach. Literacy Learning: The Middle Years, 22(2), 7-14. https://doi.org/https://eprints.qut.edu.au/75741/

Oczkus, L. (2010). Reciprocal teaching at work: powerful strategies and lessons for improving reading comprehension ((2nd ed)). International Reading Association.

Ofodu, G. O., \& Lawal, R. A. (2011). Cooperative instructional strategies and performance levels of students in reading comprehension. International Journal of Educational Sciences, 3(2), 103-107. https://doi.org/10.1080/09751122.2011.11890014

Okkinga, M., van Steensel, R., van Gelderen, A. J. S., \& Sleegers, P. J. C. (2016). Effects of reciprocal teaching on reading comprehension of low-achieving adolescents. The importance of specific teacher skills. Journal of Research in Reading, 41(1), 20-41. https://doi.org/10.1111/1467-9817.12082

Peregoy, S. F., \& Boyle, O. F. (2017). Reading, Writing, and Learning in ESL: A Resource Book for Teaching K-12 English Learners (Seventh Ed). Pearson Education, Inc.

Quirk, P. J. (2010). Using Reciprocal and Learning Methods to enhance comprehension in Mathematics word problems [Massey University Palmerston North]. http://mro.massey.ac.nz/handle/10179/2247 
Renandya, W., \& Jacobs, G. M. (2017). Cooperative learning: Addressing implementation issues. Indonesian JELT, 12(2), 101-113. https://doi.org/10.25170/ijelt.v12i2.1471

Rojabi, A. R. (2021). Exploiting SQ4R cooperative learning method to enhance EFL students' reading comprehension. Edulingua: Jurnal Linguistik Terapan Dan Pendidikan Bahasa Inggris, 7(1), 1-20. https://doi.org/10.34001/edulingua.v7i1.1160

Salehi, M., \& Vafakhah, S. (2013). A comparative study of Reciprocal Teaching Only (RTO) and Explicit Teaching of Strategies before Reciprocal Teaching (ET-RT) on reading comprehension of EFL learners. Australian Journal of Basic and Applied Sciences, 7(2), 148-155.

Snow, C. (2002). Reading for understanding: toward an R\&D Program in Reading Comprehension. Santa Monica, CA: Rand Corporation.

Spear, S. L. (2015). The power of RTI and reading profiles. A blueprint for solving reading problems. Baltimore, MD: Brookes.

Spivey, N., R. \& Cuthbert, A. (2006). Reciprocal teaching of lecture comprehension skills in college students. Journal of Scholarship of Teaching and Learning, 6(2), 66-83.

Tarchi, C., \& Pinto, G. (2016). Reciprocal teaching: Analyzing interactive dynamics in the coconstruction of a text's meaning. The Journal of Educational Research, 109(5), 518-530. https://doi.org/10.1080/00220671.2014.992583

Westerveld, M., Armstrong, R. M., \& Barton, G. M. (2020). Reading success in the primary years. Singapore: Springer Nature Singapore Pte Ltd.

Zhang, L. (2018). Metacognitive and cognitive strategy use in reading comprehension. Singapore: Springer Nature Singapore Pte Ltd. 